\title{
Alterations in cellular structure of Mytilus edulis resulting from exposure to environmental contaminants under field and experimental conditions
}

\author{
D. M. Lowe \\ Plymouth Marine Laboratory (West Hoe), Prospect Place, The Hoe, Plymouth PL1 3DH, United Kingdom
}

\begin{abstract}
This study, undertaken at the GEEP Workshop, quantifies cell and tissue changes in mussels Mytilus edulis, exposed to diverse contaminants under field and experimental conditions, and correlates the changes with changing tissue levels of PAHs, PCBs and metals. The results indicate effects on reproductive tissues in mussels exposed to high levels of contaminants, both in the field and in the mesocosm experiment. High contaminant concentrations are also seen to induce the formation of pathologically enlarged secondary lysosomes in the digestive epithelium of mussels and to cause a disturbance in lipid levels, resulting in alterations in digestive cell architecture.
\end{abstract}

\section{INTRODUCTION}

Histological, cytological and cytochemical responses to environmental contaminants, observable from animal tissue sections, form an important link between effects at the biochemical level and those measured in whole organisms. The potential of this link for explanation and prediction has been reflected in the shift of emphasis, over the past decade, from descriptive histology to semi- or fully quantitative histology, the latter exploiting the techniques of stereology to quantify the proportions (and sizes) of certain types of structure within the organism.

Whilst there is now a considerable literature on morphometric changes associated with adverse environmental conditions in a wide range of fish (Hinton \& Couch 1984), much of the quantitative histology on invertebrate responses to stress has concentrated on reproductive and digestive cells of only 3 groups: oysters, clams and mussels. Differences in reproductive and nutrient storage-cell cycles were investigated between populations of mussels in the USA by Newell et al. (1982), and in the UK by Lowe et al. (1982), whereas Bayne et al. (1978) used stereology to study the effects of nutritional and thermal stress. Maung
Myint \& Tyler (1982) described the effects on the mussel reproductive system of nutritional, thermal and metal ion stressors. The latter were also investigated by Sunila (1984), who observed degeneration of germ cells in response to exposure to copper and cadmium. Lowe $\&$ Pipe $(1986,1987)$ quantified the effects of exposure to diesel oil hydrocarbons on nutrient storage and germ cells of mussels.

In addition to changes associated with normal phasic activity (Langton 1975, Robinson 1983), effects of various contaminants on digestive tubule structure in mussels have been studied by Rasmussen (1982), Calabrese et al. (1984) and Sunila (1984); in clams, by Tripp et al. (1984) and Couch (1984); and in scallops, by Yevich \& Yevich (1985). Lowe et al. (1981) and Moore \& Clarke (1982) used stereological techniques to demonstrate that exposure to crude-oil derived hydrocarbons resulted in the formation of pathologically enlarged secondary lysosomes and other structural changes in mussel digestive cells.

This evidence of sensitivity of reproductive and digestive cell systems to environmental contaminants, coupled with the ability to quantify changes histologically, suggested their further study at the GEEP Workshop. 


\section{MATERIAL AND METHODS}

Tissue section preparation. Mytilus edulis were collected from 4 sites in Langesundfjord (Follum \& Moe 1988) and from experimental exposures to different levels of a diesel oil and copper mixture, at the Solbergstrand mesocosm facility, (L: low, $M$ : medium, $H$ : high dose, with control $\mathrm{C}$ for $\mathrm{L} \& \mathrm{M}$ samples, and control $\mathrm{CH}$ for $H$ samples; Bakke et al. 1988). Samples were received at the laboratory in coded form, and therefore analysed 'blind'. For each field site or mesocosm treatment, 15 individuals (shell length 45 to $55 \mathrm{~mm}$ ) were selected, and the digestive gland and 1 mantle lobe excised. The digestive gland was sliced transversely into 4 portions of approximately equal thickness and fixed, in conjunction with the mantle lobe, in Bakers formal calcium $(+2.5 \% \mathrm{NaCl})$ for 3 h at $4{ }^{\circ} \mathrm{C}$. Following fixation, the first and third slices from the anterior end of the digestive gland were transferred, together with a slice of mantle lobe, to $70 \%$ alcohol for $30 \mathrm{~min}$ and then into absolute alcohol for $1 \mathrm{~h}$. The dehydrated tissues were then impregnated in a 2, hydroxyethylmethacrylate monomer solution overnight and then embedded in monomer plus activator (Lewis \& Bowen 1985). The blocks were allowed to polymerize for $3 \mathrm{~h}$, removed from the moulds, and air dried on the bench prior to sectioning with Ralph glass knives. Sections (2 um) were floated out directly onto slides on distilled water and dried on a hot plate at $60^{\circ} \mathrm{C}$ for ca $3 \mathrm{~min}$, prior to staining on the hot plate for $15 \mathrm{~s}$, in Lee's methylene blue-basic fuchsin, and mounting in colophonium resin (Difco). A second group of sections were stained using an extended Schmorl ferroferricyanide reaction $(10 \mathrm{~min}$ ) to demonstrate lipofuscin in residual bodies which, because of the prolonged staining, also imparts non-specific colour to secondary lysosomes. Small pieces of fixed digestive gland were also removed from several mussels from mesocosm treatments $\mathrm{C}, \mathrm{CH}$ and $\mathrm{H}$, and treated with osmium tetroxide $(1 \%$ solution in a $0.1 \mathrm{M}$ phosphate buffer, $\mathrm{pH} 7.2$ ) for $3 \mathrm{~h}$, dehydrated in $70 \%$ alcohol (60 min) and impregnated with methacrylate as previously described. Sections $(2 \mu \mathrm{m})$ were cut, mounted and observed unstained to determine the distribution of the osmiophilic lipids in the digestive and pyramidal cells. Similarly, pieces of fixed digestive gland were removed from several mussels, washed for $1 \mathrm{~h}$ in a $0.75 \mathrm{M}$ sucrose in $0.1 \mathrm{M}$ phosphate buffer to remove the formalin, and frozen sections $(5 \mu \mathrm{m})$ cut and stained in oil red 0 to demonstrate unsaturated neutral lipids. This second lipid reaction allowed comparison with the results for the osmicated material previously described.

Tissue section analysis. Mussel mantle tissue was considered in terms of its 2 storage cell types, adipogranular cells (Froutin 1937) and vesicular connective tissue cells (Lubet 1959), as well as the various developmental stages of gametes within the reproductive follicles, and the intra-follicle spaces around gametes resulting from spawning activity and/or degeneration. The proportions of these cell types were determined using stereological techniques (Weibel 1979, Lowe et al. 1982), which determine the relative proportion (termed 'volume density') of chosen cell types within a tissue, by simple point counting on tissue sections. The cellular composition of the mantle is highly homogeneous, with random (isotropic) orientation of its cellular components; therefore, a single random section per animal was considered sufficient. The sampling fields, 5 per section, were determined by systematic sampling from a random start point (Weibel 1979), and analysed at magnifications of $\times 500$ (females) and $\times 800$ (males). Differences between field sites, or experimental conditions, were examined by 1 way analysis of variance, followed by multiple comparison tests on specific pairs of means. A more detailed account of the application of stereological techniques to mussel mantle tissues can be found in Bayne et al. (1985).

Digestive gland condition of mussels from the various sites and treatments was assessed in terms of the following specific indicators, previously identified as pathological and/or signifying a reduction in organism fitness: parasitic infestation (Sindermann et al. 1980), granulocytomas (Lowe \& Moore 1979), presence of pathologically enlarged secondary lysosomes (Lowe et al. 1981, Moore \& Clarke 1982), pyramidal cell vacuolation, tubule dilation (Lowe et al. 1981), epithelial cell breakdown (Calabrese et al. 1984, Pipe \& Moore 1986) and digestive epithelium vesiculation (Wolfe et al. 1981). A digestive gland section for each mussel was screened for presence of the above conditions and differences in incidence between treatments/sites tested by $\chi^{2}$. In addition, all sections were screened for evidence of neoplastic conditions. Maximum diameters $\left(d_{\text {max }}\right)$ of the granular component of heterogeneous secondary lysosomes and residual bodies were determined using a Kontron IPS image analyzer interfaced to a Riechert Polyvar microscope at $\times 2000$ magnification.

\section{RESULTS}

\section{Mantle tissues \\ Field samples}

Volume densities of components of the mantle tissues are given in Table 1 . The only significant differences involved Site 3, where Mytilus edulis had higher per- 
Table 1. Mytilus edulis. Volume density (\%) of components of mantle tissue of mussels from field sites and mesocosm basins (mean $\pm \mathrm{SE}, n=15$ )

\begin{tabular}{|c|c|c|c|c|}
\hline Source & Gamete & $\begin{array}{l}\text { Atretic } \\
\text { gamete }\end{array}$ & $\begin{array}{c}\text { Total } \\
\text { gamete }\end{array}$ & $\begin{array}{c}\text { Storage } \\
\text { cells }\end{array}$ \\
\hline \multicolumn{5}{|l|}{ Site } \\
\hline 1 & $9.6 \pm 4.2$ & $3.0 \pm 1.4$ & $23.7 \pm 5.9$ & $69.9 \pm 5.7$ \\
\hline 2 & $12.7 \pm 2.5$ & $3.4 \pm 1.7$ & $28.0 \pm 5.4$ & $65.5 \pm 5.5$ \\
\hline 3 & $18.4 \pm 2.8^{\circ}$ & $6.5 \pm 3.0$ & $44.0 \pm 5.6^{\circ}$ & $47.2 \pm 4.6^{\circ}$ \\
\hline 4 & $8.6 \pm 3.0$ & $10.6 \pm 4.3$ & $36.5 \pm 5.9$ & $58.0 \pm 5.7$ \\
\hline \multicolumn{5}{|l|}{ Basin } \\
\hline C & $39.5 \pm 4.2$ & $1.8 \pm 1.0$ & $77.3 \pm 5.9$ & $19.8 \pm 5.4$ \\
\hline $\mathrm{L}$ & $27.2 \pm 6.9^{\circ}$ & $0.7 \pm 0.3$ & $40.8 \pm 9.0^{\circ}$ & $42.9 \pm 7.4^{\circ}$ \\
\hline$M$ & $35.8 \pm 3.8$ & $2.9 \pm 1.5$ & $71.7 \pm 6.3$ & $16.1 \pm 4.4$ \\
\hline $\mathrm{CH}$ & $25.7 \pm 5.2$ & $0.6 \pm 0.3$ & $37.5 \pm 7.1$ & $59.2 \pm 6.9$ \\
\hline $\mathrm{H}$ & $6.6 \pm 2.2 \cdots$ & $6.5 \pm 2.6^{\circ}$ & $23.8 \pm 5.2$ & $74.0 \pm 5.2$ \\
\hline \multicolumn{5}{|c|}{$\begin{array}{l}\text { Significant difference from the reference site ( } 1 \text { ) or rele- } \\
\text { vant control condition (C or CH) indicated by }{ }^{\circ} p<0.05 \text {, } \\
\because p<0.01\end{array}$} \\
\hline
\end{tabular}

centages of gamete and total gamete (i.e. gamete, atretic gamete and space) and a correspondingly lower volume fraction of storage cells than at other sites.

\section{Mesocosm samples}

Mantle tissue components are again given in Table 1. Comparisons were made between $\mathrm{L}$ and $\mathrm{M}$ basins and their control $\mathrm{C}$ (15 wk exposure) and between the $\mathrm{H}$ condition and its control $\mathrm{CH}$ ( 3 wk exposure). $\mathrm{C}$ and $\mathrm{CH}$ mussels were also compared to obtain information on possible containment effects or intra-population differences.

Volume density of gametes was significantly greater in $\mathrm{C}$ than $\mathrm{CH}(p<0.05)$, and storage reserves significantly lower $(p<0.01)$; atretic gamete volume did not differ between the 2 controls. In the long-term exposures, Treatment L showed significantly lower fractions of gamete and total gamete than $C$ and $M$, with a correspondingly higher percentage of storage reserves. In the short-term exposures, there was no significant difference in total gamete fraction between $\mathrm{CH}$ and $\mathrm{H}$ but the composition was markedly different, with significantly less gamete, and more atretic gamete, for $\mathrm{H}$ than $\mathrm{CH}$. All males from treatment $\mathrm{H}$ exhibited atypical asynchronous gamete development and sperm resorption (Fig. 1a).

\section{Digestive gland}

Histochemical tests for lipids showed that many of the structural alterations observed in the digestive epithelium of Mytilus edulis were due to increased lipid accumulations (Figs. 2a, b, c) associated with enlarged secondary lysosomes (Fig. 2d). A second consequence of exposure was the formation of another type of greatly enlarged secondary lysosome with a granular matrix (Fig. 2d), resulting from the fusion of smaller lysosomes. This second form was surrounded by a layer of discrete lipid droplets (Fig. 2c). Increased levels of lipids were also observed in the pyramidal cells of the digestive epithelium (Fig. 2e, f). Whilst it is not uncommon to observe some lipid droplets in pyramidal cell cytoplasm, the large accumulations shown here are abnormal.

\section{Field samples}

Figs. 3 and 4 summarise the incidence data for the potential 'effects indicators' listed earlier. Parasitic infestation of mussels at Site 1 was significantly higher than at Site 2 and was absent altogether at Sites 3 and 4. The parasites involved were larval trematodes, including metacercariae (inducing a limited host response) and sporocysts containing cercaria, the latter resulting in castration of the host in 2 instances. Small numbers of granulocytomas were observed in mussels from all sites, with no significant differences. There were differences, however, in incidence of pathologically enlarged secondary lysosomes. The heterogeneous type were present in significant numbers only at Site 3 . The homogeneous lipid-rich type were prevalent at all 3 contaminated field sites ( 2 to 4 ), a similar pattern to that found for pyramidal cell vacuoles and epithelial cell breakdown, though in the latter case Site 3 stood out as having a more major incidence. Tubule dilation, which appeared to be unrelated to starvation or nutrient deprivation, showed a different pattern, Sites 1 and 3 having higher incidences than 2 and 4 ; the exact converse was seen for epithelium vesiculation (the result of excessive accumulation of lipid droplets).

\section{Mesocosm samples}

Figs. 5 and 6 summarise incidence data for the same set of effects indicators. Parasitism was virtually absent from the long-term exposed mussels but both parasite burden and incidence were high in the short-term exposures. Incidence of granulocytomas was low in all groups, as was the case for both types of enlarged secondary lysosomes, with the clear exception of the $\mathrm{H}$ treatment. Maximum diameter $\left(d_{\max }\right)$ of the granular component of heterogeneous enlarged lysosomes had a mean of $3.35 \mu \mathrm{m}$ for $\mathrm{CH}_{1}$ and of $5.03 \mu \mathrm{m}$ for $\mathrm{H}$ mussels; $d_{\text {max }}$ of residual bodies was $2.09 \mu \mathrm{m}$ for $\mathrm{CH}$ and $2.76 \mu \mathrm{m}$ 


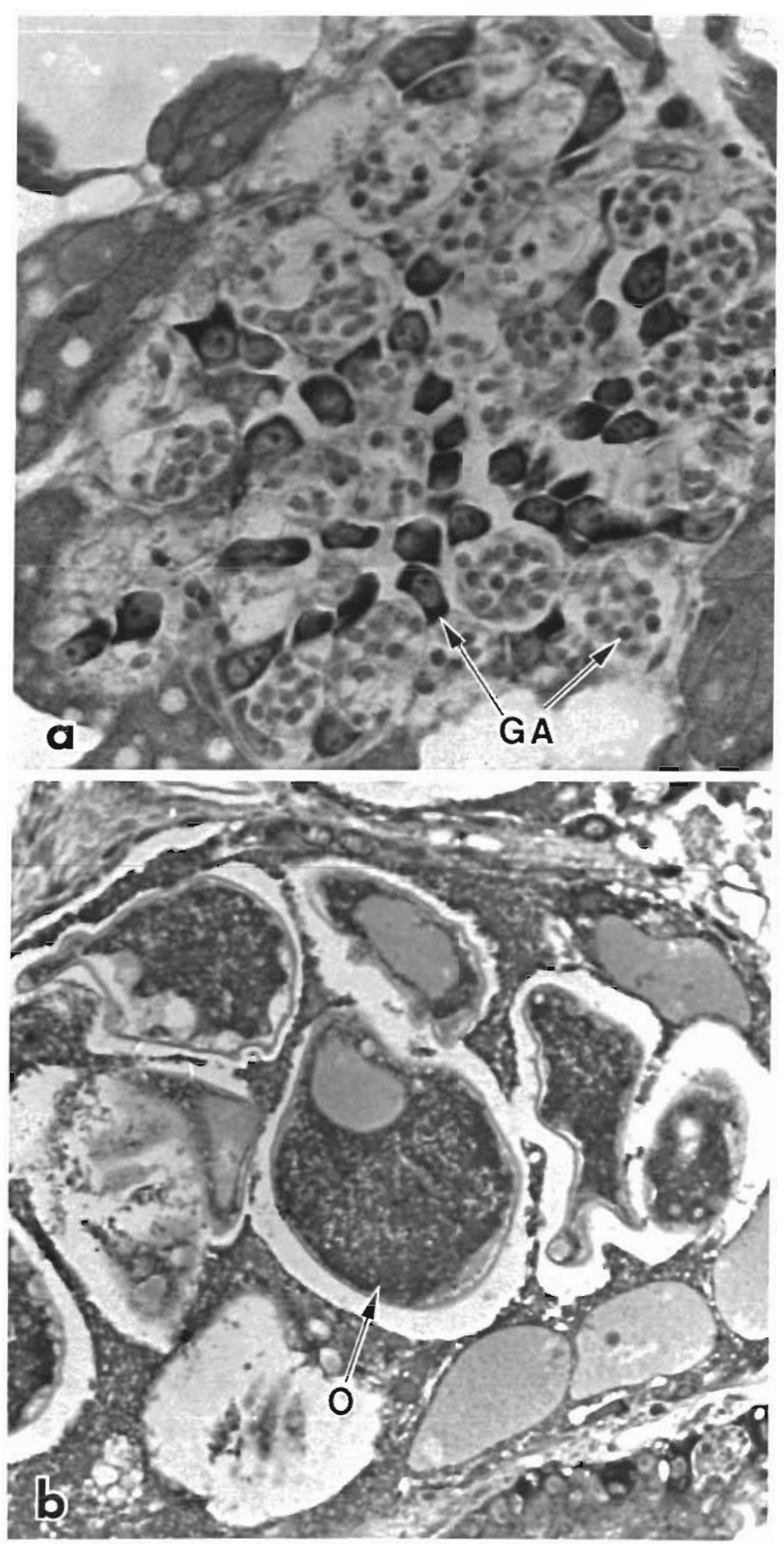

Fig. 1 Mytilus edulis. (a) Male reproductive tissue exhibiting atypical gamete development (GA); (b) female gametes (O) exhibiting disruption following exposure in experimental condition $\mathrm{H} . \times 1000$ 

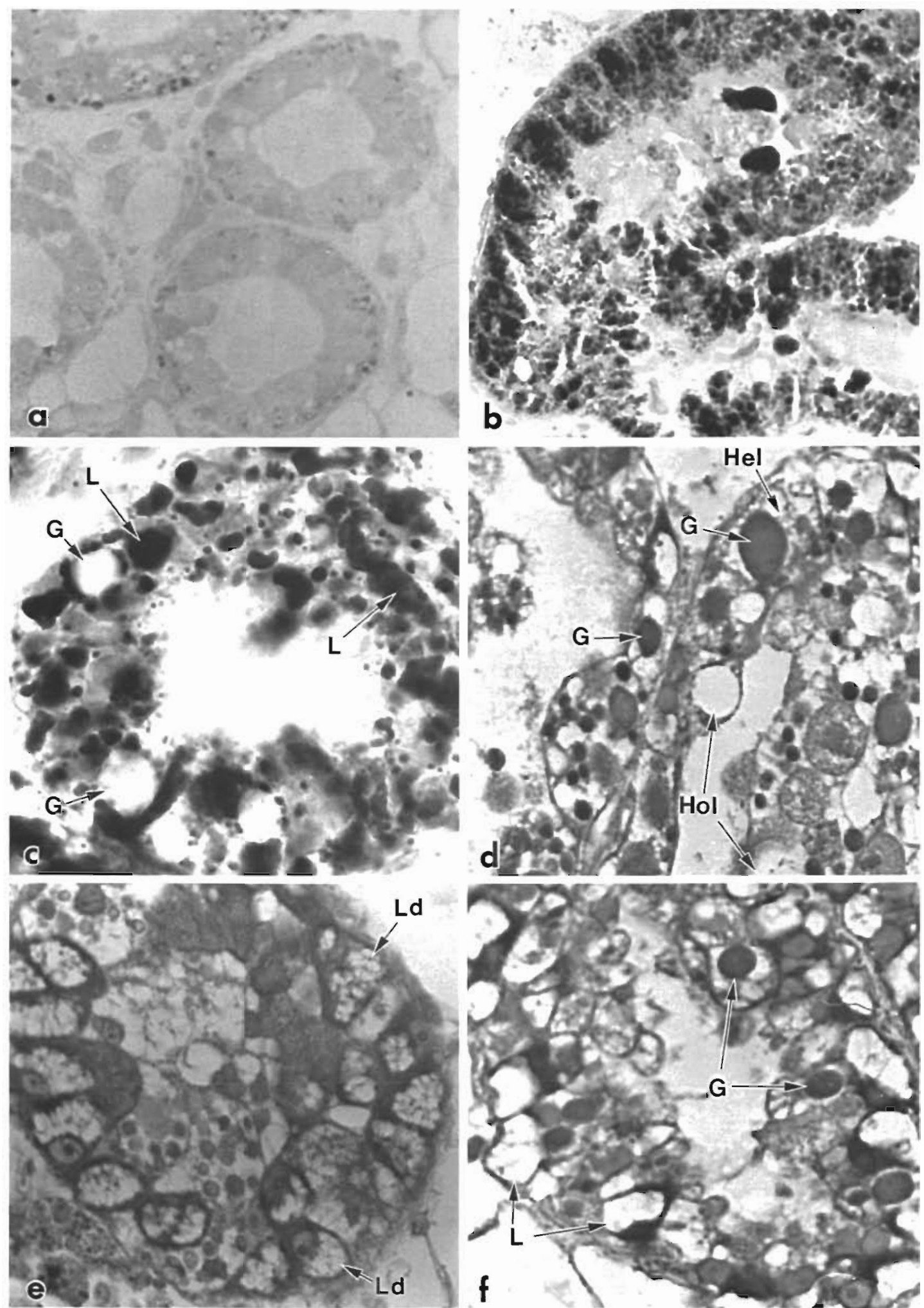

Fig. 2. Mytilus edulis. (a,b) Unstained $(2 \mu \mathrm{m})$ section of post-osmicated digestive gland tissue, showing black osmiophilic lipid deposits in the digestive tubule epithelium; mesocosm experimental condition (a) $\mathrm{CH}$, (b) H. (c) Frozen section (5 um), stained with oil red 0 , and (d) periodic acid Schiff stained section $(2 \mathrm{\mu m})$, of digestive tubules from experimental condition $\mathrm{H}$, showing lipid accumulations ( $L_{1}$ ), homogeneous pathologically enlarged secondary lysosomes (Hol) and granular matrix (G) of heterogeneous pathologically enlarged secondary lysosomes (Hel), surrounded by lipid droplets. (e,f) Section (2 $\mu \mathrm{m}$ ), stained with Lee's

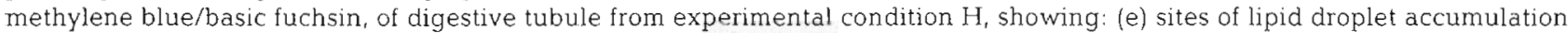
(Ld) in pyramidal cells of the digestive epithelium; (f) large lipid vacuoles (L) in the pyramidal cells resulting from fusion of small lipid droplets; also pathologically enlarged heterogeneous secondary lysosomes with granular matrix $(G)$. $(a, b) \times 500 ;(c$ to $f)$ 

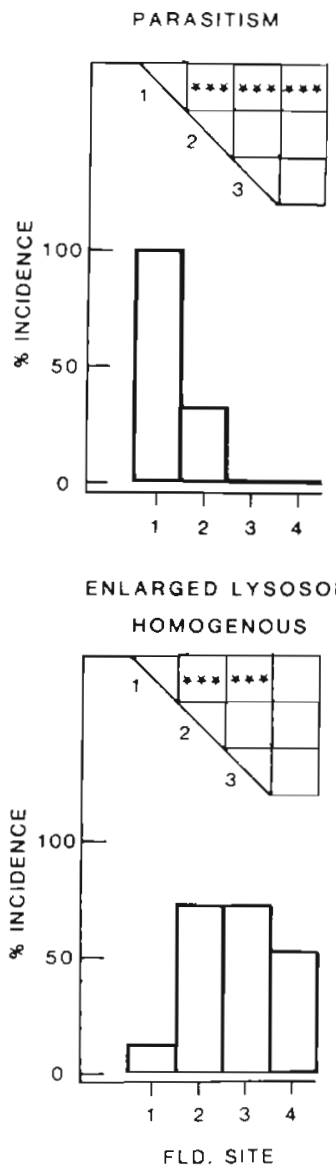

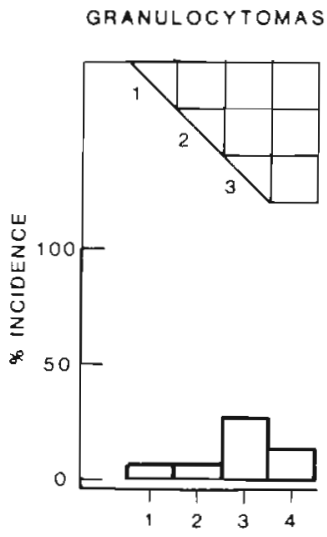

ENLARGEO LYSOSOMES HETEROGENOUS

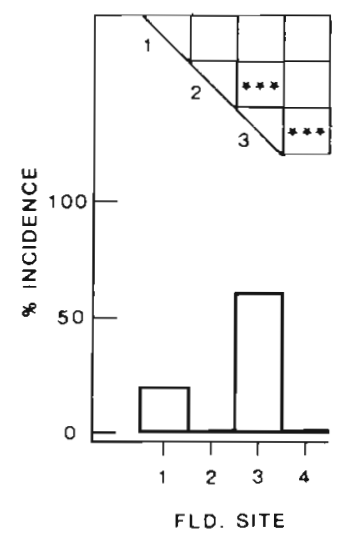

Fig. 3. Mytilus edulis. Incidence of parasitism, granulocytomas and enlarged lysosomes in digestive gland cells from the 4 field sites $(\%, n=15)$. Significant differences between all pairs of sites indicated in an upper triangular matrix by - $p<0.05, \cdots p<0.01, \cdots p<0.001$

for $\mathrm{H}$. Both differences were significant $(p<0.01)$. The pattern was repeated for pyramidal cell vacuolation and tubule breakdown, with a high incidence for the $\mathrm{H}$ group and virtual absence elsewhere; in contrast, epithelium vesiculation was not significantly different between treatments.

The general appearance of the digestive tubules suggested that mesocosm mussels in the long-term exposure were not receiving sufficient food; the expected range of tubule types was not present and their staining characteristics were typical of a nonactive resting condition (Fig, 7b). Thus, although tubule dilation was apparent (Fig. 6), it appeared more due to lack of food than contamination; tubule epithelium architecture remained essentially normal. Treatment $\mathrm{H}$ was quite different, with a thinning of the digestive epithelium due to loss of apical cytoplasm; this was frequently seen in the lumen, containing intact residual bodies and secondary lysosomes.
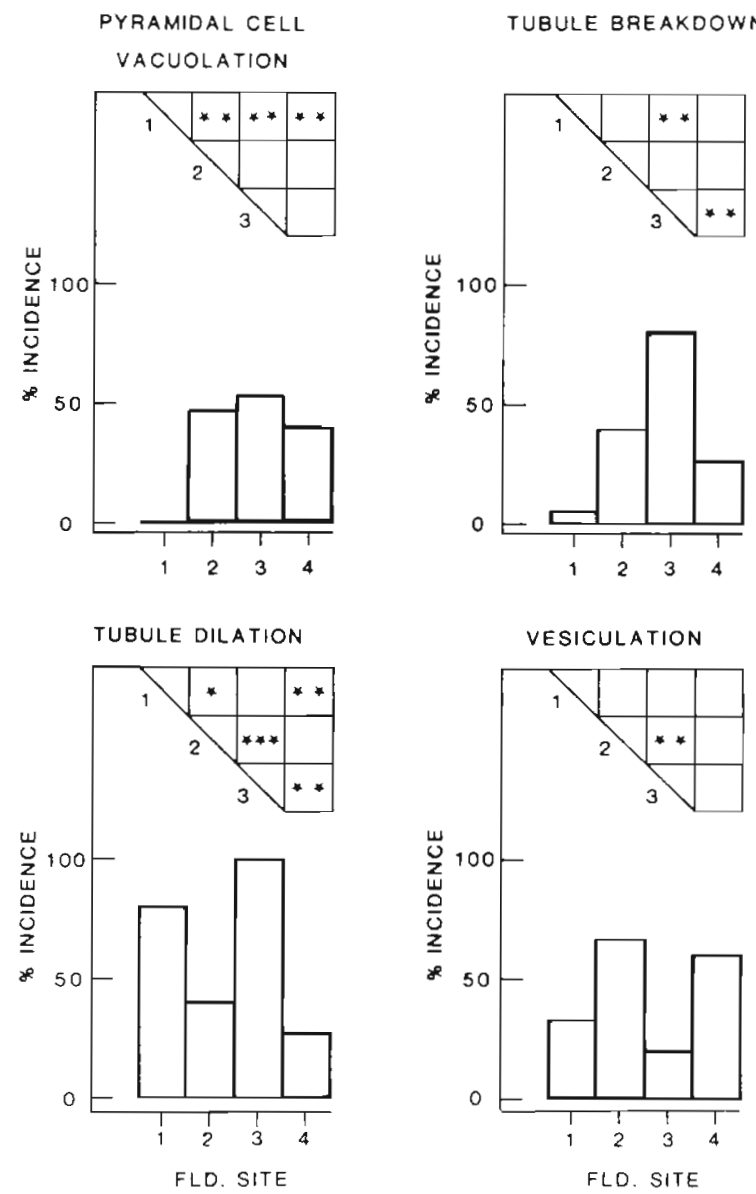

Fig. 4. Mytilus edulis. Incidence of pyramidal cell vacuolation, tubule dilation and epithelial cell breakdown and vesiculation of digestive gland cells from the 4 field sites $(\%, n=15)$. Significance levels as for Fig. 3

\section{DISCUSSION}

The objectives of this study were to determine and quantify alterations in the cell and tissue architecture of Mytilus edulis exposed to contaminants (including PAHs, PCBs and metals), and to correlate alterations with contaminant concentration. One problem with such a correlative exercise is the implicit assumption that the effects of particular (groups of) compounds are additive, and that increasing concentration implies increased toxicity when in fact the toxic threshold may be exceeded in the 'cleanest' field site or lowest dose condition.

The analysis of mantle tissue cells and the various specific indicators of pathology used here have, for the most part, been used previously in pollution related studies. However, neither the alterations induced in pyramidal cell architecture by lipid accumulation, nor the formation of pathologically enlarged heterogene- 


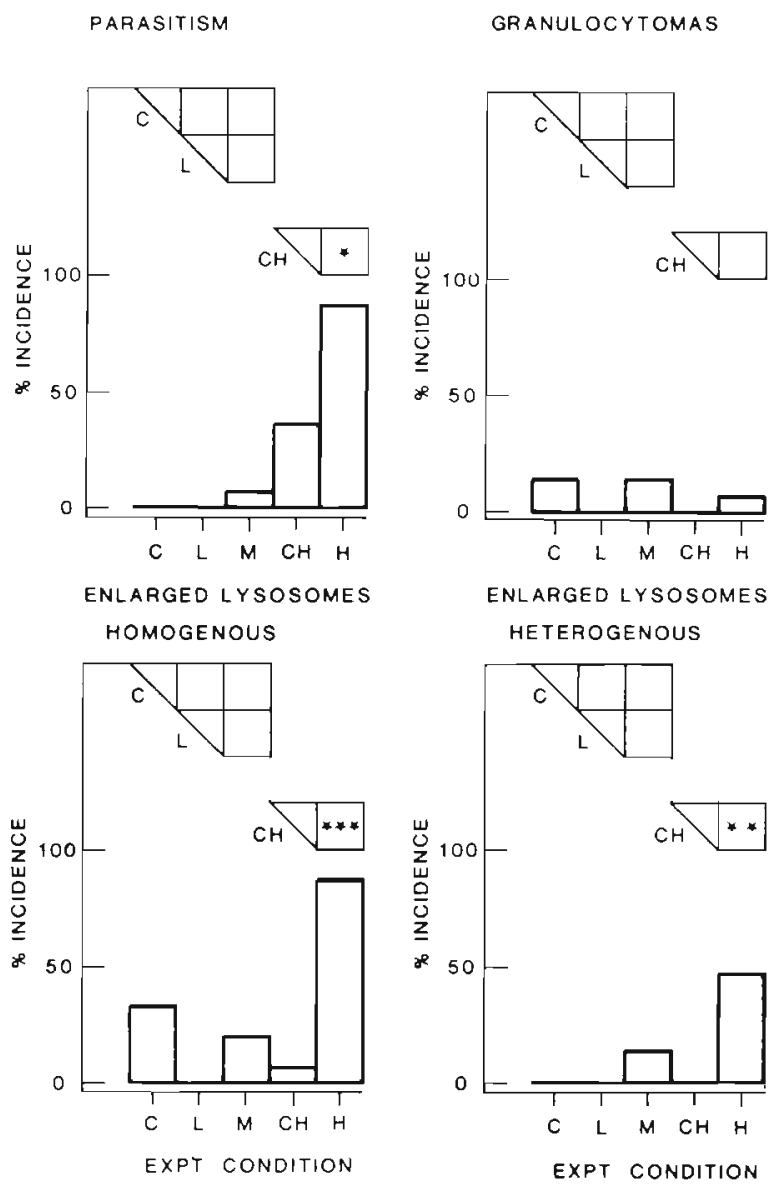

Fig. 5. Mytilus edulis. Incidence of specific indicators of effects (as in Fig. 3) from mesocosm experimental conditions

ous secondary lysosomes have been identified before as a consequence of pollutant exposure.

Although parasitism is considered in these studies, it is not thought to reflect a reduction in the resistance capacity (as discussed by Sindermann et al. 1980) but is, rather, a natural site-dependent variable. Indeed, Field Site 1 had the highest incidence of parasitism but the lowest tissue contaminant burdens.

The chemical analysis of Mytilus edulis tissues (Klungsøyr et al. 1988) exhibit a clear gradient of PAHs and PCBs across Field Sites 1 to 4 . Individual hydrocarbon levels are, roughly speaking, a constant proportion of the total PAHs measured, indicating a dilution effect across the fjord sites. Two exceptions are: (1) the naphthalenes do not increase along the general gradient (in fact naphthalene itself decreases by a factor of 2 to 5); (2) increases in other compounds between Sites 1 and 4 tend to be greater for higher molecular weight compounds than for lower ones (Appendix 1, Table 4). Whilst there is an undeniable gradient in total PAHs from Sites 1 to 4 , these variations could have some bearing on any interpretation of the cytological obser-
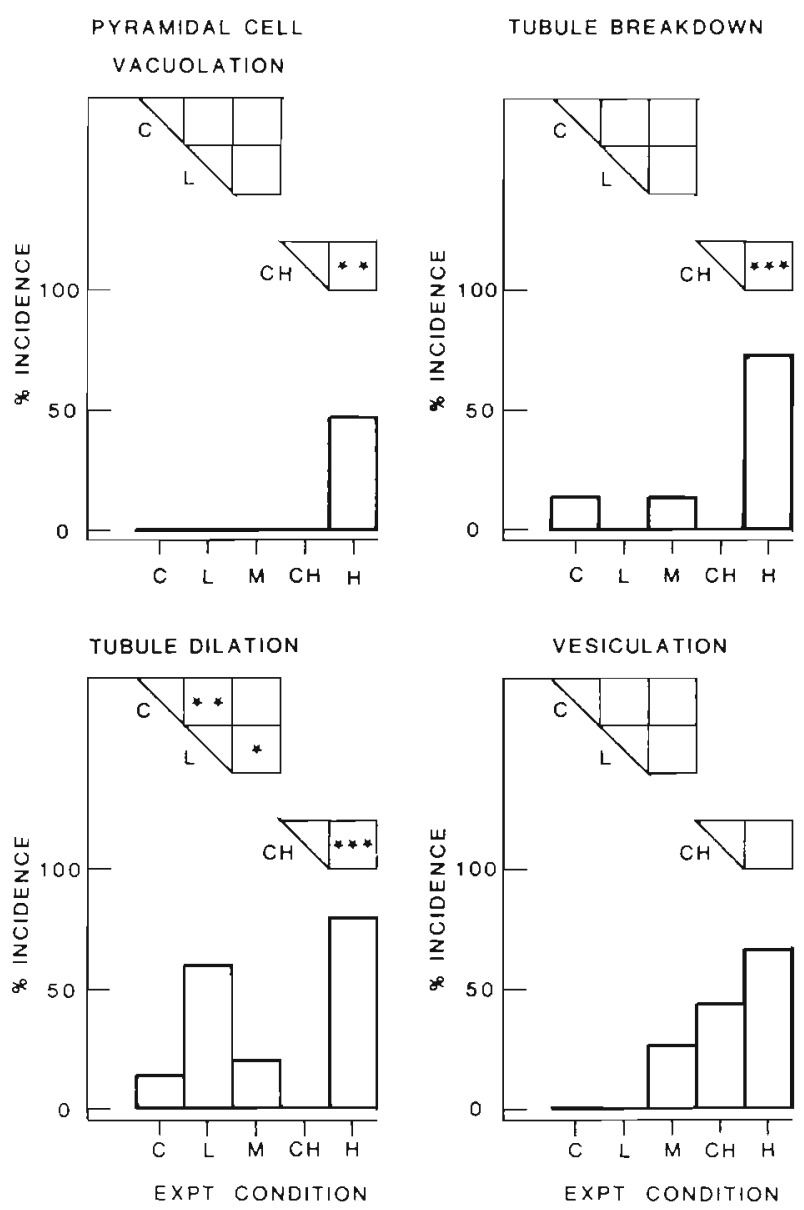

Fig. 6. Mytilus edulis. Incidence of specific indicators of effects (as in Fig. 4) from mesocosm experimental conditions

vations. Another factor affecting interpretation of $\mathrm{PAH}$ gradients is the gametogenic condition of the mussels. Mytilus edulis that are ripe but have not spawned contain considerable reserves of lipids; PAHs are lipophilic and comparisons of their concentrations in mussel tissue should take this into account.

The indications from the analyses of the mantle tissues were that Site 1 mussels had spawned and were recovering (and this would have lowered their hydrocarbon burden). Site 2 and 3 mussels had commenced spawning, as had those at Site 4 , though mussels from 4 had a high proportion of degenerating germ cells; the latter have previously been demonstrated to be a consequence of exposure to hydrocarbons (Lowe \& Pipe 1987).

The overall condition of digestive gland tubules from all sites was poor, though Site 1 mussels tended to be in slightly better condition, and Site 3 worse than the average. On several counts there were no significant differences between Sites 1 and 4, reflecting the poor condition of Site 1 mussels. Whether the slightly elevated levels of naphthalenes at Site 1 are a contributory 

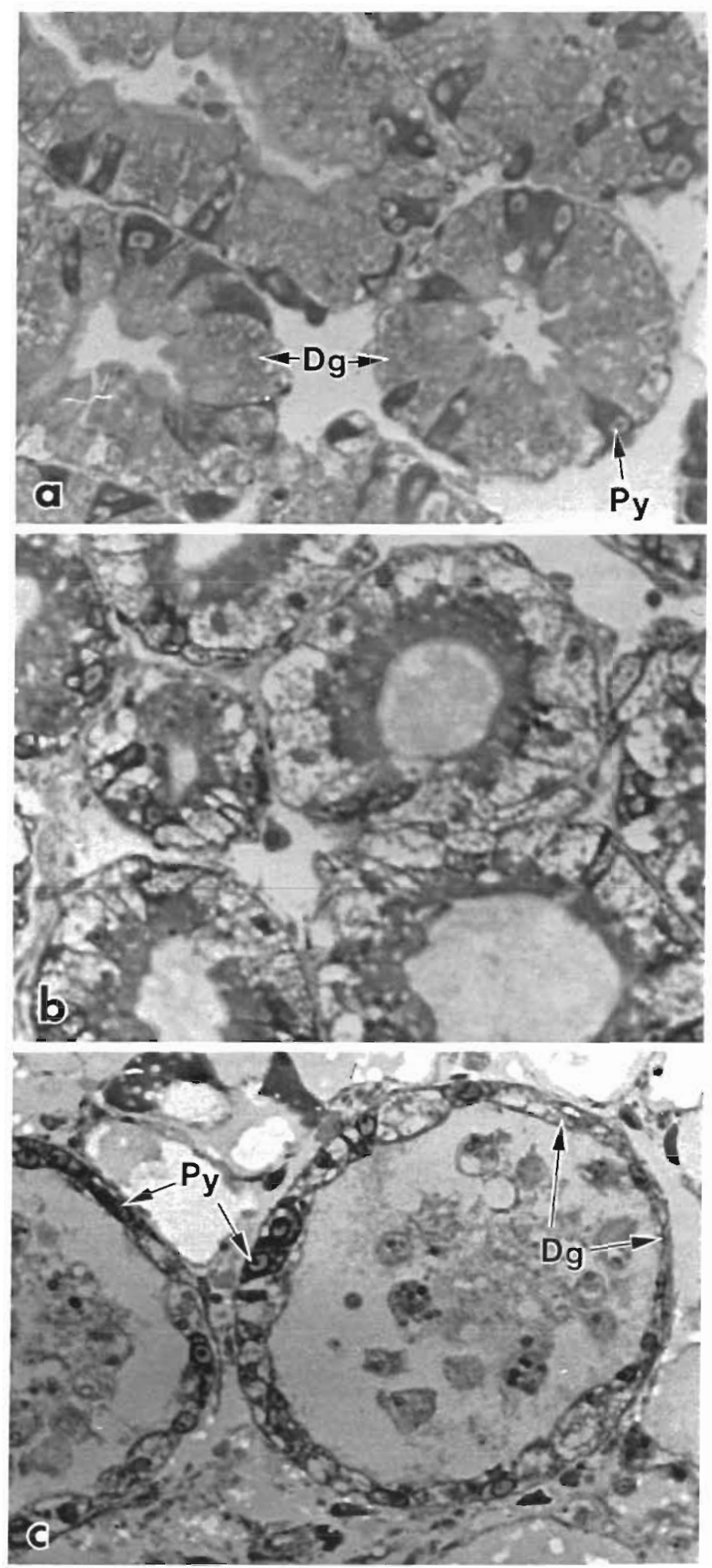

Fig. 7 Mytilus edulis. Section ( $2 \mu \mathrm{m})$, stained with Lee's methylene blue/basic fuchsin, showing structure of digestive tubules from the mesocosm experiment: (a) $\mathrm{CH}$ condition showing normal digestive cells (Dg) and pyramidal cells (Py); (b) $\mathrm{M}$ condition: in resting phase due to nutritional deprivation; (c) $\mathrm{H}$ condition exhibiting epithelial cell shrinkage and erosion. $\times 500$ 
factor here is unknown but exposure to hydrocarbons has been demonstrated to induce the formation of enlarged secondary lysosomes (Lowe et al. 1981, Moore \& Clarke 1982) and these were present at Site 1

For the mesocosm experiment, the PAH fluorescence measurements (Bakke et al. 1988) showed a clear trend in water concentrations across the 4 basins, in line with the dosing (though dosing levels were rather variable). The trend was reflected in the pronounced accumulation of PAHs in whole mussel tissues over the 4 conditions (Klungsøyr et al. 1988). Mantle tissues from the 2 control groups of mesocosm mussels demonstrated distinctly different phases in the nutrient storage/reproductive cycle, supporting the decision to make comparisons only within the groups $(\mathrm{C}, \mathrm{L}, \mathrm{M})$ and $(\mathrm{CH}, \mathrm{H})$. The almost total absence of parasites in $\mathrm{C}, \mathrm{L}$ and $\mathrm{M}$ mussels, compared to the high incidence in $\mathrm{CH}$ and $\mathrm{H}$, is probably a reflection of the slight difference in location from which the 2 stocks were drawn.

Mantle tissue analyses from the long-term exposures identify treatments $\mathrm{C}$ and $\mathrm{M}$ as similar but $\mathrm{L}$ as somewhat different, though there was no significant difference in the percentage of atretic gamete between the 3 treatments. A factor which might have been expected to depress fecundity was the lower temperature of the mesocosm water $\left(6\right.$ to $10^{\circ} \mathrm{C}$ over the 4 mo period) compared to ambient field temperatures (surface water 5 to $18^{\circ} \mathrm{C}$ ); Sastry \& Blake (1971) observed reduced fecundity in scallops maintained at less than ambient temperatures during gamete development. However, any effect of this sort should apply equally to all basins. The condition of the digestive gland in the long-term exposures $(C, L, M)$ is very similar, and this is attributed to nutritional deprivation (Widdows \& Johnson 1988), resulting in the digestive tubules entering a resting phase

In the short-term exposures, Mytilus edulis from $\mathrm{CH}$ had more gamete, fewer storage cells and less atretic gamete than from $\mathrm{H}$. The stereological analysis of Lowe $\&$ Pipe (1987) suggests that mussels have the capacity to resorb germinal material during periods of stress, diverting the potential energy recovered back into the storage pool. This may be the explanation for the greater reserves in $\mathrm{H}$ mussels. The condition of digestive gland tubules is significantly different in $\mathrm{H}$ than $\mathrm{CH}$ mussels, in almost all respects, and the observed effects are strongly indicative of pollution induced pathology

In conclusion, histological analysis of mussels from both mesocosm treatments and field sites indicate effects of contaminants on digestive epithelial cells and germinal cells. The major effect of exposure on the digestive epithelium appears to be an increase in lipids; whether this is due to inability to catabolise lipids, an increase in lipid synthesis or an impairment of neurosecretory control mechanisms associated with storage and reproductive cycles (Mathieu 1979) is not apparent. Gamete degeneration (atresion) appears to be the main effect on the germinal tissues.

These analyses identified Field Site 1 as being the least impacted, although the mussels were not considered to be in good condition even from this site. Site 3 and 4 mussels exhibited higher proportions of degenerating gametes, the specific pathological indicators suggesting that digestive tissues of Site 3 mussels were in poorer condition than those of Site 4 mussels: Site 3 is therefore deemed as being the most disturbed. This strict lack of agreement between the biological evidence of pollutant impact and the anticipated impact based on tissue chemistry, may be due to a lack of understanding of the more subtle effects of complex pollutant 'cocktails' and the toxic thresholds (Warren 1971) of the individual components of the pollutants.

\section{LITERATURE CITED}

Bakke, T., Follum, O. A., Moe, K. A., Sorensen, K. (1988). The GEEP Workshop: mesocosm exposures. Mar. Ecol. Prog. Ser $46: 13-18$

Bayne, B. L., Brown, D. A., Burns, K., Dixon, D. R., Ivanovici, A., Livingstone, D. R., Lowe, D. M., Moore, M. N., Stebbing, A. R. D., Widdows, J. (1985). The effects of stress and pollution on marine animals. Praeger, London

Bayne, B. L., Holland, D. L., Moore, M. N., Lowe, D. M., Widdows, J. (1978). Further studies on the effects of stress in the adult on the eggs of Mytilus edulis. J. mar. biol. Ass. U.K. 58: 825-841

Calabrese, A., MacInnes, J. R., Nelson, D. A., Greig, R. A., Yevitch, P. P. (1984). Effects of long-term exposure to silver or copper on growth, bioaccumulation and histopathology in the blue mussel Mytilus edulis. Mar. environ. Res. 11 . $253-274$

Couch, J. A. (1984). Atrophy of diverticular epithelium as an indicator of environmental irritants in the oyster. Crassostrea virginica. Mar. environ. Res. 14: 525-526

Follum, O. A., Moe, K. A. (1988). The GEEP Workshop: field sampling. Mar. Ecol. Prog. Ser. 46: 7-12

Froutin, G. H. (1937). Contributions a l'etude du tissu conjonctif des mollusques det plus particulierment des lamellibranches et des gasteropodes. D. Sc. thesis, Univ. Paris

Hinton, D. E., Couch, J. A. (1984). Pathobiological measures of marine pollution effects. In: White, $H$. H. (ed.) Concepts in marine pollution measurements. Maryland Sea Grant Publication, p. $7-32$

Klungsøyr, J., Wilhelmsen, S., Westrheim, K, Saetvedt, E., Palmork, K. H. (1988). The GEEP Workshop: organic chemical analyses. Mar. Ecol. Prog. Ser. 46: 19-26

Langton, R. W. (1975). Synchrony in the digestive diverticula of Mytilus edulis L. J. mar. biol. Ass. U.K. 55: 221-229

Lewis, G. H. J., Bowen, I. D. (1985). A methacrylate embedding technique for combined autoradiography and acid phosphatase histochemistry. Histochem. J. 17: 467-475

Lowe, D. M., Moore, M. N. (1979). The cytology and occurrence of granulocytomas in mussels. Mar Pollut. Bull. 10: $137-141$ 
Lowe, D. M., Moore, M. N., Bayne, B. L. (1982). Aspects of gametogenesis in the marine mussel Mytilus edulis L. J. mar. biol. Ass. U.K. 62: 133-145

Lowe, D. M., Moore, M. N., Clarke, K. R. (1981). Effects of oil on digestive cells in mussels: quantitative alterations in cellular and lysosomal structure. Aquat. Toxicol. 1: $213-226$

Lowe, D. M., Pipe, R. K. (1986). Hydrocarbon exposure in mussels: a quantitative study on the responses in the reproductive and nutrient storage cell systems. Aquat Toxicol. 8: 265-272

Lowe, D. M., Pipe, R. K. (1987). Mortality and quantitative aspects of storage cell utilization in mussels, Mytilus edulis, following exposure to diesel oil hydrocarbons. Mar environ. Res. (in press)

Lubet, P., (1959). Recherches sur le cycle sexual et l'emission des gametes chez les Mytilides et les Pectinides. Rev. Trav. off. Pêches maritimes 23: 396-545

Mathieu, M. (1979). Etude experimentale du controle neuroendocrinien des cycles de developpement de la gonacle et du tissu de reserve chez la moule adulte Mytilus edulis L. (Mollusque Lamellibranche). D. Sc. thesis, Univ. Caen

Maung Myint, U., Tyler, P. A. (1982). Effects of temperature nutritive and metal stressors on the reproductive biology of Mytilus edulis. Mar. Biol. 67. 209-223

Moore, M. N., Clarke, K. R. (1982). Use of microstereology and quantitative cytochemistry to determine the effects of crude oil-derived aromatic hydrocarbons on lysosomal structure and function in a marine bivalve mollusc, Mytilus edulis. Histochem. J. 14: 713-718

Newell, R. I. E., Hilbish, I J., Koehn, R. K., Newell, C. J. (1982). Temporal variation in the reproductive cycle of Mytilus edulis (Bivalvia, Mytilidae) from localities on the east coast of the United States. Biol. Bull. mar. biol. Lab., Woods Hole 162: 299-310

Pipe, R. K., Moore, M. N. (1986). Arylsulphatase activity associated with phenanthrene induced digestive cell deletion in the marine mussel Mytilus edulis. Histochem. J. 18: $557-564$
Rasmussen, L. (1982). Light microscopical studies of the acute toxic effects of $\mathrm{N}$-Nitrosodimethylamine on the marine mussel, Mytilus edulis. J invert. Pathol. 39: 66-80

Robinson, W. E. (1983). Assessment of bivalve intracellular digestion based on direct measurements. J. mollusc Stud. 49: $1-48$

Sastry, A. N., Blake, N. J. (1971). Regulation of gonad development in the bay scallop Aequipecten irradians Biol. Bull. mar. Biol. Lab., Woods Hole 140: 274-283

Sindermann, C. J., Bang, F. B., Christensen, N. O., Dethlefsen, V., Harshbarger, J. C., Mitchell, J. R., Mulcahy, M. F (1980). The role and value of pathology in pollution effects monitoring programs. Rapp. P.-v. Réun. Cons. int. Explor Mer 179: 135-151

Sunila, I. (1984). Histopathological changes in the mussel Mytilus edulis L. at the outlet from titanium dioxide plant in Northern Baltic. Annis. Zool. fenn. 23: 61-70

Tripp, M. R., Fries, C. R., Craven, M. A., Grier, C. E. (1984). Histopathology of Mercenaria mercenaria as an indicator of pollutant stress. Mar environ. Res. 14: 521-524

Warren, C. E. (1971). Biology and water pollution control Saunders and Co., Philadelphia

Weibel, E. R. (1979). Stereological methods, Vol. 1: Practical methods for biological morphometry. Academic Press, London

Widdows, J., Johnson, D. (1988). Physiological energetics of Mytilus edulis: Scope for Growth. Mar. Ecol. Prog. Ser. 46 113-121

Wolfe, D. A., Clarke, R. C. Jr, Foster, C. A., Hawkes, J. W., Macleod, W. D. Jr (1981). Hydrocarbon accumulation and histopathology in bivalve molluscs transplanted to the Baie de Morlaix and the Rade de Brest. In: Amoco Cadiz. Fates and effects of the oil spill. Proc. Int. Symp. Centre Oceanogique de Bretagne, Brest, p. 599-616

Yevich, C. A., Yevich, P. P. (1985) Histopathological effects of cadmium and copper on the sea scallop Placopecten megellanicus. In. Vernberg, F. J., Thurberg, F. P., Calabrese, A., Vernberg, W. (eds.) Marine pollution and physiology: recent advances. Univ, South Carolina Press, p. $187-198$ 